\title{
Benthic invertebrate activity in lakes: linking present and historical bioturbation patterns
}

\author{
David S. White ${ }^{1, *}$, Molly F. Miller ${ }^{2}$ \\ ${ }^{1}$ Hancock Biological Station, 561 Emma Drive, Murray, Kentucky 42071, USA \\ ${ }^{2}$ Department of Earth and Environmental Sciences, Box 35-0117, 2301 Vanderbilt Place, Vanderbilt University, Nashville, \\ Tennessee 37235, USA
}

\begin{abstract}
Trace fossils of lacustrine benthos are less well known than those of marine benthos, limiting their potential use in interpreting paleo-environmental conditions, including climate change, reconstructing lake ecosystems, and predicting effects of sediment mixing of paleoclimate records. Here, we present a synopsis of limnological controls on the distribution of present day lacustrine benthos, a synopsis of their burrowing and feeding habits, and a summary of the traces they produce. Maximum diversity and density of benthos occur in sublittoral zones and decrease both shoreward and basinward. Common taxa include bivalves (unionids, sphaeriids), snails, oligochaetes, amphipods, and insects (particularly chironomids and ephemeropterans). With a few exceptions, traces produced are morphologically simple, shallowly inscribed, and have low preservation potential. Although lacustrine benthic organisms are widespread, variability within and between lakes causes them and their traces to be patchily distributed. To truly understand the records left in lacustrine sediments and the links between modern and ancient traces, we need comprehensive surveys over a range of lake types and collaborations between ichnologists and benthic ecologists.
\end{abstract}

KEY WORDS: Lake benthos $\cdot$ Lacustrine fauna $\cdot$ Lake ecology $\cdot$ Paleolimnology $\cdot$ Ichnofacies

Resale or republication not permitted without written consent of the publisher

\section{INTRODUCTION}

Interpretation of marine sedimentary environments has been greatly enhanced by integration of studies of modern traces and their producers with studies of trace fossils and their facies distributions (see examples in W. Miller 2007). In spite of recent work on lacustrine ichnology (e.g. Buatois \& Mangano 2007), the contribution of lacustrine biogenic structures to understanding depositional systems lags behind their marine counterparts. One major barrier to ichnologists, who are overwhelmingly marine oriented, is dissimilarity between lacustrine and marine systems and organisms (Miller \& White 2007). Because of the small size and isolation of many lakes, important environmental controls, particularly water mixing patterns and distribution of productivity, are highly variable and different from those in the marine realm. As a result, the lacustrine and marine terminologies are not the same, which hinders communication.
A second impediment to lacustrine ichnology is the disconnection between lacustrine trace fossils and the behavior of modern benthic animals in lakes. The large-scale actuo-paleontologic programs, the results of which provided the firm uniformitarian basis for marine ichnology in the 1930s (see Cadée \& Goldring 2007), have not been undertaken in lacustrine settings. Coordinated studies must occur before the potential of lacustrine ichnology in elucidating paleoecologic, paleoclimatic, and depositional histories of lakes can be realized. Problem areas include: (1) linking lacustrine benthic animals with the traces produced; (2) correlating modern lacustrine traces typically observed in vertical section and trace fossils commonly preserved on bedding planes; (3) collecting data on the distribution and abundance of infaunal animals in modern lakes and on rates of bioturbation; (4) determining responses of lacustrine benthic fauna to changes in productivity and mixing; and (5) gathering quantitative information on the abundance, type, and facies 
distributions of trace fossils and bioturbation in ancient lakes, including Paleozoic lakes extant prior to vegetative cover.

This paper describes the trace-producing activities of the most abundant lacustrine benthic animals, and summarizes their abundance and distribution. It relates modern traces to lacustrine trace fossils, and identifies barriers and unknowns. Finally, it addresses the extent of disruption of modern and ancient lacustrine sediments by biogenic structures and bioturbation, underscoring the need for data from both modern and ancient deposits in order to reconstruct the Phanerozoic history of lacustrine benthic activity.

\section{DISTRIBUTION OF LACUSTRINE BENTHOS}

The benthic environment of any lake is related to combinations of water column productivity (trophic status) and circulation (mixis) and sediment deposi-

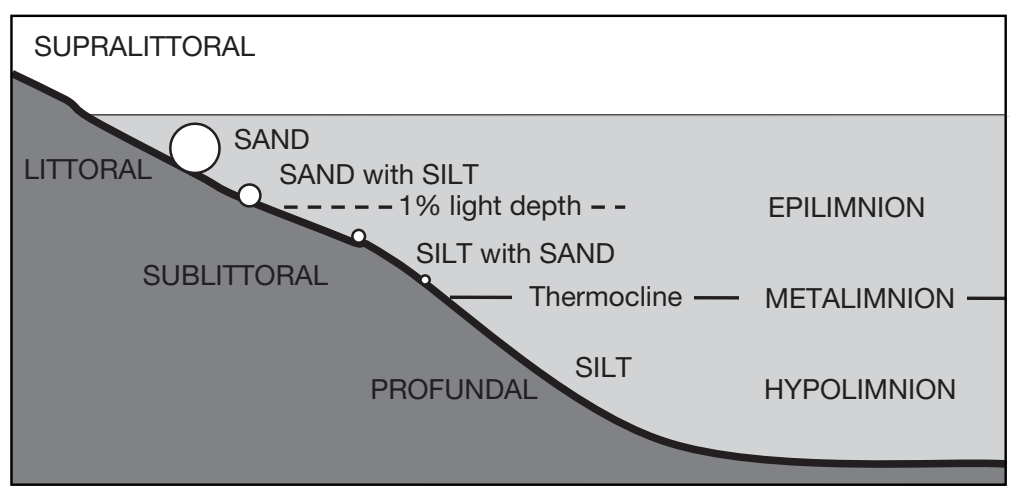

Fig. 1. Benthic and water column zones from shoreline to basin during summer stratification, showing resuspension probabilities (circles) and sediment types. In most lakes, summer stratification periods establish distributions of lacustrine benthos that occur throughout the year (after White et al. 1986, Wetzel 2001)

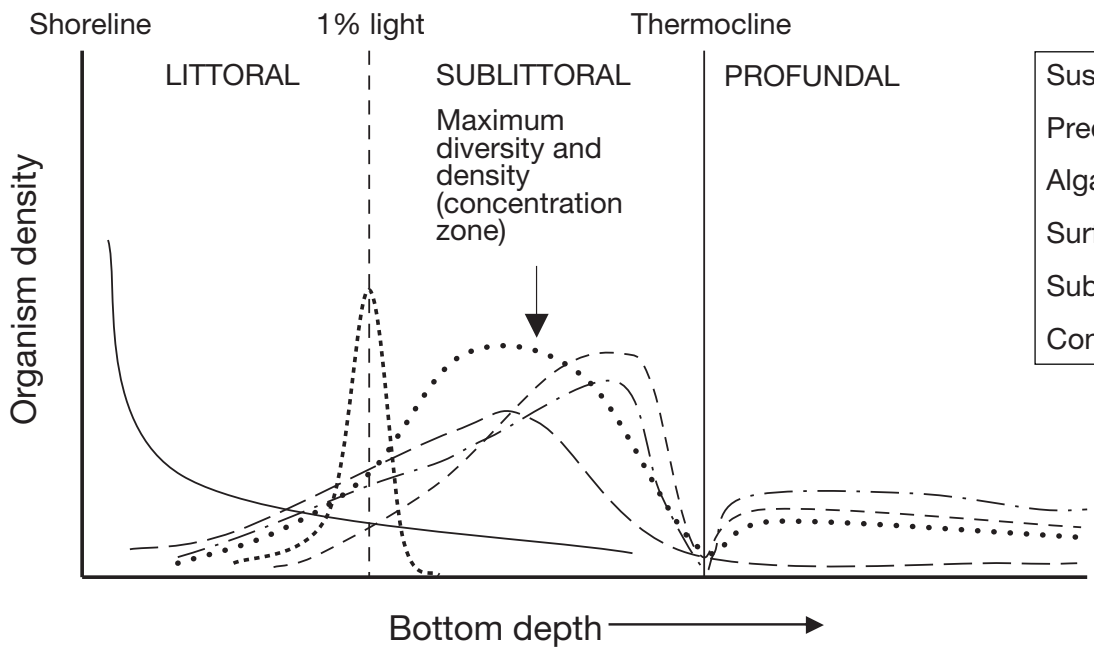

Fig. 2. Benthic invertebrate structure from shoreline to basin in oligotrophic Lake Michigan (after White et al. 1986). Similar patterns have been noted for many lakes (Mackie 2001) 
energy and the resulting decrease in resuspension and winnowing (White et al. 1986). Wave-induced resuspension is rare in the profundal zone (Fig. 1), and sediment movement is caused primarily by biological activity and rare physical events such as thermal-bar scouring (Wetzel 2001).

The distribution of benthic invertebrates generally follows the littoral to profundal patterns described above (Fig. 2; White et al. 1986, Wetzel 2001). Maximum benthos density and diversity usually occur in the sublittoral zone in what has been termed the 'concentration zone' (Mackie 2001). Concentration zones often correspond with water column depths that are about 1.5 times the depth of light penetration (White et al. 1986, Mackie 2001). In most lakes, concentration zones (Fig. 2) occur between 2 and $4 \mathrm{~m}$ water depth, but may be as deep as 17 to $18 \mathrm{~m}$ in large oligotrophic lakes (Mackie 2001, Martin et al. 2005). The benthos is greatly reduced or absent below the thermocline in mesotrophic to eutrophic lakes, but may be found at depths up to 100 s of meters in oligotrophic lakes (Fig. 2; Martin et al. 1994, 2005).

\section{BIOGENIC STRUCTURES IN MODERN LAKES}

Biogenic structures commonly reflect feeding activities and/or concealment behaviors (Figs. 3 \& 4; Thorp \& Covich 2001, Merritt et al. 2007). The terminology used for freshwater organisms differs from that used for marine organisms (Bromley 1996). In the broadest sense, collectors feed on deposited or suspended organic matter and associated bacteria. Collector feeding mechanisms include: (1) filter feeding on suspended or resuspended particles; (2) surface gathering of particles at the sediment-water interface; (3) subsurface gathering of buried organic matter, usually in oxidized surficial sediments; and (4) subsurface conveyor-belt feeding that vertically displaces buried particles. Suspension filterers tend to dominate nearshore littoral environments (Figs. 1 \& 2), while surface and subsurface gatherers and conveyor-belt feeders dominate where resuspension events rarely occur (White et al. 1986). The distribution of algal grazers corresponds with the maximum abundance of benthic algae, which usually occurs at or just above the depth of the $1 \%$ light level (Stevenson \& Stoermer 1981).

While there is considerable information on areal distributions, feeding habits, and secondary production of lacustrine benthos (Thorp \& Covich 2001), the behavior of most taxa remains poorly known or is inferred from only a few descriptions (e.g. Brinkhurst 1974). This is largely due to the lack of laboratory and in situ observations. In general, the 2 main forms of bioturbation in lake sediments are eddy-diffusive and conveyor-belt mixing (Rhoads 1974). Eddy-diffusive mixing, the simple lateral or vertical movement of sediments, is more common and results in most types of traces, particularly those seen on bedding planes. Conveyor-belt mixing, the vertical displacement of sediments through feeding, is limited primarily to deposit-feeding aquatic annelids (e.g. Tubificidae, Lumbriculidae). While 100 s of benthic invertebrate species may exist in any lake, the number of phyla is usually small (Hutchinson 1993), particularly those capable of bioturbation or of being preserved as body fossils or trace fossils. The primary groups are Mollusca (Bivalvia, Gastropoda), Annelida (particularly Oligocheata), and Arthropoda (Insecta and Crustacea, particularly Amphipoda and Isopoda).

All bivalves are aquatic and many live buried in the substrate (McMahon \& Bogan 2001). With the exception of Pisidium, lacustrine bivalves are water-column suspension feeders found in fairly shallow littoral or
Fig. 3. Idealized drawing of lacustrine benthic community from Lake Michigan showing interactions with sediment (after White et al. 1986). Community components would not be expected to all occur at the same location and might be in much higher or lower densities, depending on lacustrine conditions

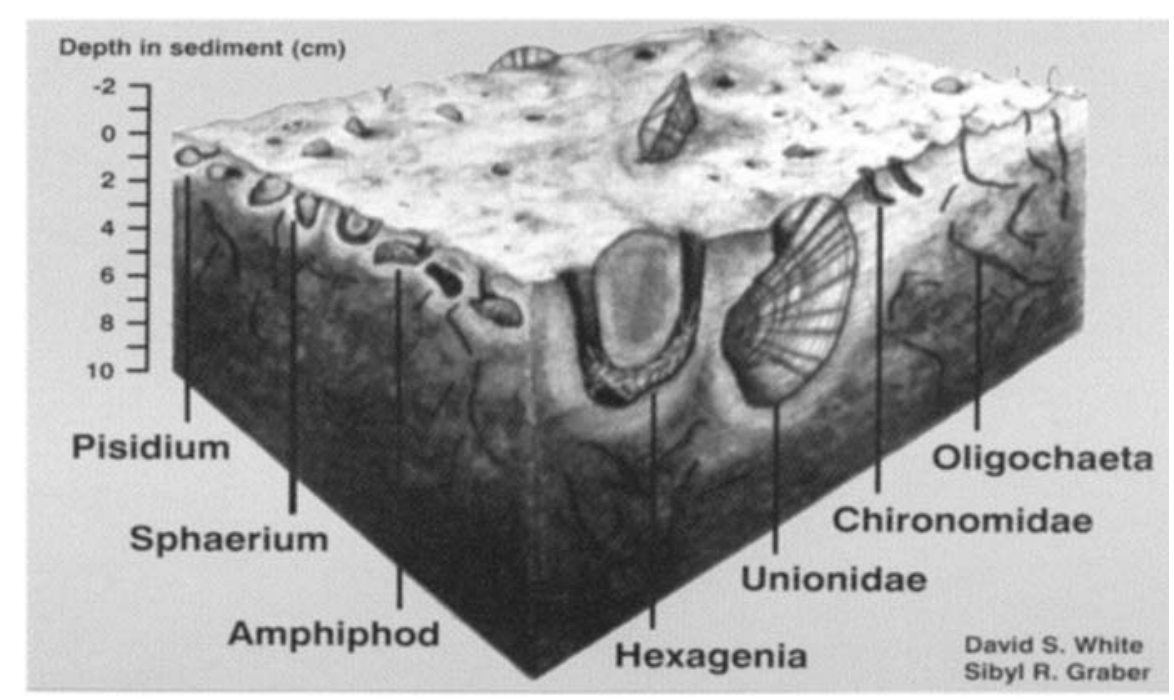



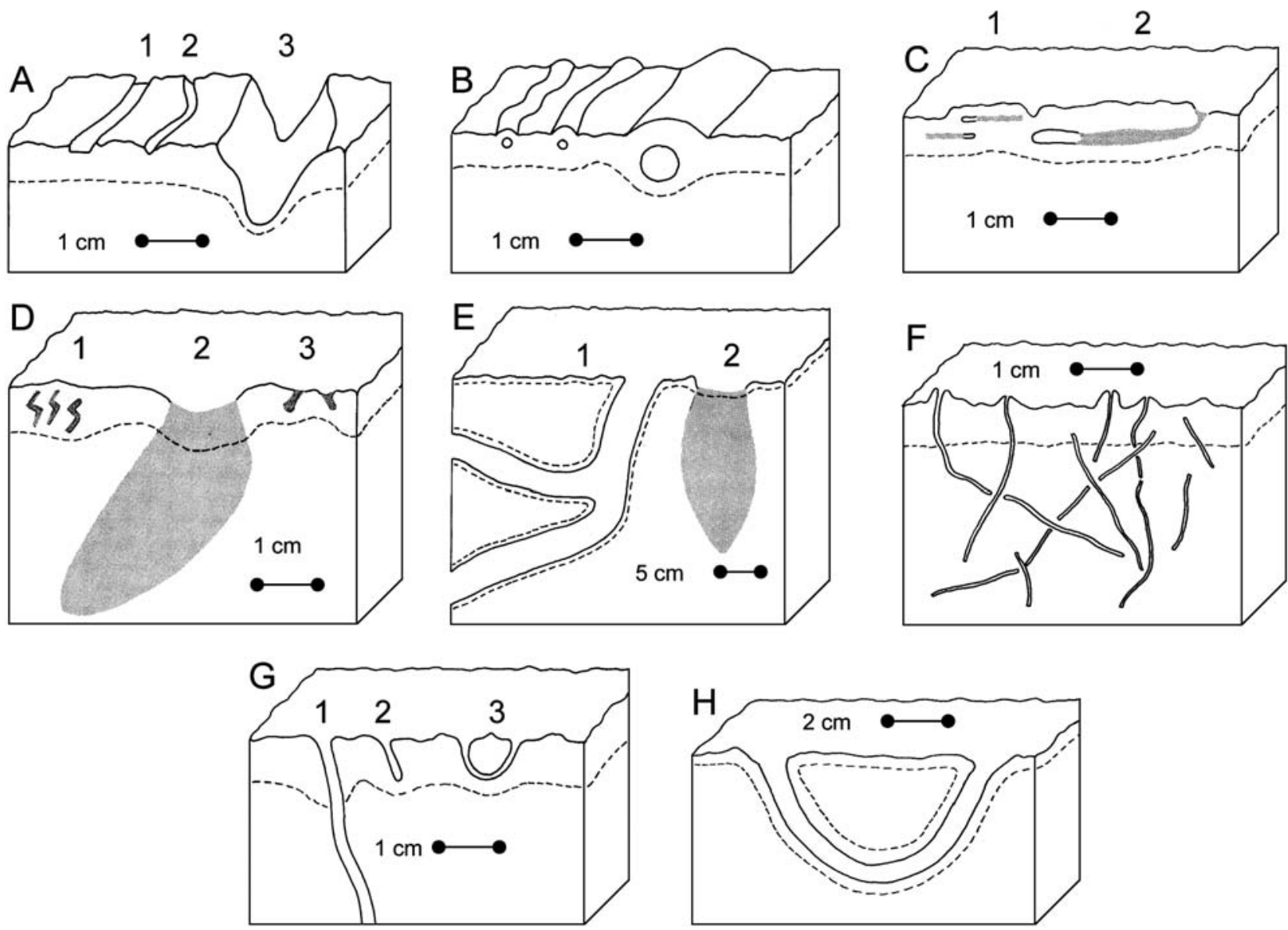

Fig. 4. Tracks and traces left by typical freshwater lacustrine benthos. (A) Surface traces left by (1) gastropods and (2 \& 3 ) bivalves. (B) Subsurface burrows potentially left by burrowing amphipods, bivalves, and aquatic insects. (C) Backfilled burrows of (1) Pisidium and (2) amphipods. (D) Backfilled subsurface traces left by (1) Chaoborus, (2) small Unionidae and (3) Sphaerium. (E) (1) Crayfish burrow and (2) backfilled large Unionidae trace. (F) Tubificidae traces. (G) (1) Large chironomid trace, (2) J-shaped chironomid tube and (3) U-shaped chironomid tube. (H) Hexagenia burrow. Dotted lines represent predicted depths of oxidized sediments

sublittoral habitats. Bivalves actively move within or upon sediments (Wu 1987), but the traces produced are often difficult to ascribe to a particular species (Figs. 3 \& 4A-E). Bioturbation by bivalves is eddy diffusive (White et al. 1986), and traces of burrows should be recognizable in sediment cores for long periods of time (Fig. 4D,E). Pisidium, with its greatly reduced siphon, burrows through sediments (Mackie et al. 1980) (Figs. 3 \& 4B,C). Pisidium occurs in high densities in sublittoral and profundal sediments of oligotrophic lakes; $>20$ species and densities of up to 1000 ind. $\mathrm{m}^{-2}$ are found in the sublittoral zone of Lake Michigan (Zdeba \& White 1985). The constant movements of Pisidium result in eddy-diffusive homogenization of surficial sediments (White et al. 1986).

More than 1000 species of lake-dwelling snails are known, and they feed primarily on periphyton and detritus (Harman \& Berg 1971, Thorp \& Covich 2001). Although some taxa (e.g. Limnaeidae) may burrow temporarily into soft sediments, most graze continually using their muscular foot to glide over surfaces at or above the $1 \%$ light level. Traces (Fig. 4A) are generally similar for most freshwater species (shallow and narrow, $<1 \mathrm{~cm}$ wide), and bioturbation is eddy diffusive.

Annelids, particularly Tubificidae and Lumbriculidae, spend much of their life cycles buried where they feed on sediments and associated bacteria (Brinkhurst \& Cook 1980). Oligochaetes feed in a conveyor-belt mode, more or less in a vertical position, with the head downward and the anus at or below the sedimentwater interface (Figs. $3 \& 4$ F). Surface defecation may leave small fecal mounds (Figs. $3 \& 4 \mathrm{~F}$ ), but most individuals probably defecate below the surface. Densities, species composition, feeding rates, and feeding depths depend on the deposition rate of new organic matter. Where sediment deposition rates are high, such as in embayments and deltas, feeding and mixed depths may exceed $15 \mathrm{~cm}$ (Robbins et al. 1989). Popu- 
lation densities $>10000$ ind. $\mathrm{m}^{-2}$ occur in oligotrophic lakes. Several species often occur together, each feeding at a different depth in the sediment and relying on each other's fecal matter as a food resource (Keilty et al. 1988). Endostratal trails produced by oligochaetes are narrow (generally $<2.0 \mathrm{~mm}$ wide), very irregular, and often appear in seemingly random patterns (Figs. $3 \& 4$ F). Much of the feeding occurs below the oxidized surface layer, and traces tend to remain open in cores for long periods of time because few other benthic organisms venture that deeply into the substrate (Martin et al. 2005). Sediment reworking by oligochaetes can quickly obliterate the traces of other benthic taxa produced at shallower levels; a similar phenomenon has been documented in marine sediments (Bromley 1996). There is often a negative relationship between oligochaete densities and densities of species that build more permanent structures, presumably because oligochaete activities disrupt burrow functions (see Brinkhurst \& Jamieson 1971). Few burrowing oligochaetes occur nearshore; they reach maximum diversity in sublittoral bottom sediments and maximum densities in profundal areas of oligotrophic lakes (Brinkhurst \& Cook 1980, White et al. 1986).

Several genera and families of amphipods and isopods are known to burrow through surficial sediments feeding on detrital organic matter and associated bacteria. The burrowing patterns of Euporeia (= Amphipoda: Pontoporeia) and Caecodotea (= Isopoda: Asellus) appear to be typical of most taxa. Euporeia and Gammaridae are the most abundant benthic invertebrates in nearshore environments of the Laurentian Great Lakes, other glacially formed lakes, and deep-rift lakes (Marzolf 1965, Martin et al. 2005), but amphipods and isopods are uncommon in other types of lakes. Amphipods remain buried during the day, feeding on organic particles and bacteria, backfilling their trails as they go (Figs. 3 \& 4B,C). Euporeia and some Gammaridae occur in the deepest zones of glacial oligotrophic lakes but reach maximum density just above the thermocline (White et al. 1986). Amphipods are often the dominant eddy-diffusive mixers of the sublittoral and profundal zones.

Chironomidae (Diptera, non-biting midges) are the most abundant and diverse aquatic insects, with $>20000$ species (Merritt et al. 2007). Chironomid larvae are the most common insects in lakes and have long played a role in lake classification in relation to trophic status (Wetzel 2001). The majority of lacustrine chironomids are small, $<1 \mathrm{~cm}$ long, and few details are known of their life histories or behavior. Most live either on the sediment surface or buried no more than 1 to $2 \mathrm{~cm}$ deep in a wide variety of substrates from sand to silty clays. Chironomids are found in all benthic zones, reaching maximum species diversity in sublittoral areas. Sergentia koschowi larvae occur at depths of $1360 \mathrm{~m}$ in Lake Baikal (Linevich 1971). Hemoglobin respiratory pigments allow larvae to persist in lowoxygen environments of mesotrophic to eutrophic lakes (Pinder 1995, Gingras et al. 2007). Many taxa create 1 to $2 \mathrm{~cm}$ long, silk-lined U- or J-shaped burrows (Figs. $3 \& 4 \mathrm{G}$ ), where they presumably remain for much of their life cycles, often a year, feeding on detritus or algae, or preying on zooplankton or other small invertebrates (Ford 1962, White et al. 1986). Other species, particularly of the genus Chironomus, move throughout the sediment creating endostratal trails similar to oligochaete traces (Figs. $3 \& 4 \mathrm{G}$ ). Phantom midge larvae (Chaoborus) are planktonic predators that exhibit vertical nightly migrations. During the day, larvae return to the sediments constructing small S-shaped burrows up to a centimeter long (Fig. 4D). Overall, sediment mixing by chironomids is eddy diffusive, but the nature of the bioturbation produced by non-tube-building taxa is unknown.

Ephemerids (burrowing mayflies) are large and perhaps the most spectacular burrowing insects in lakes, particularly the genus Hexagenia. Hexagenia nymphs build U-shaped burrows, often with many sidechambers that may extend 5 to $10+\mathrm{cm}$ deep into the fine-grained, firm substrate that they prefer (Figs. 3 \& $4 \mathrm{H})$. Nymphal life span for most species is 1 or $2 \mathrm{yr}$, and an individual may build numerous burrows in a single season. Carr \& Hiltunen (1965) reported densities of up to 2000 individuals $\mathrm{m}^{-2}$ in western Lake Erie with burrows stacked upon each other in apartment house fashion. Where densities are high, eddy-diffusive bioturbation can be extensive. Hexagenia nymphs are most common in littoral and sublittoral zones and are intolerant of dissolved-oxygen concentrations $<1 \mathrm{ppm}$ (Madenjian et al. 1998). They are surface-deposit gatherers, but also may filter organic particles brought in by currents through the burrows (Carr \& Hiltunen 1965).

Although not as abundant as the taxa mentioned above, a number of other invertebrates may leave traces in or on lake sediments. Among these are crayfish (Decapoda) and larvae of the insect families Tabanidae (Diptera), Sialidae (Neuroptera), Coleoptera (several families), Polycentropodidae (Trichoptera), and Tridactylidae (Orthoptera). Crayfish burrows probably have had the most detailed study of any of the major freshwater taxa (e.g. Hasiotis \& Mitchell 1993), with Horwitz \& Richardson (1986) providing a general classification scheme. Burrows range from simple tunnels to highly complex structures with numerous branches (Fig. 4G), similar to those described for marine callianassid shrimp (Bromley 1996). Burrowing usually occurs in the upper portions of the 
littoral and the supralittoral zones and can play a significant role in bioturbation if densities are high.

Predatory insects, such as Sialidae, Polycentropodidae, and Tabanidae, can be common in shallow, protected lacustrine margins, particularly in association with rooted vegetation, and may also occur occasionally on the open lake floor. Most construct U-, I-, or J-shaped burrows similar to, but usually larger than chironomid burrows (see Fig. 4G). Other aquatic insects burrow just beneath the sediment-water interface, and their traces (Fig. 4B) can be indistinguishable from those made by other benthic organisms. Coleoptera are unique among aquatic insects in that both adults and larvae can share the same habitats and resources. Numerous species occur along the shoreline of both marine and freshwater habitats and are known to burrow just beneath the sediment-water interface (White \& Roughley 2007). Coleoptera have been proposed as possible tracemakers for ichnofossils of the Mermia ichnofacies (see e.g. Buatois \& Mangano 1995).

\section{COMPARING TRACE FOSSILS AND MODERN TRACES}

With very few exceptions (e.g. Hasiotis 2007), references to limnological or aquatic biological studies are absent in studies of lacustrine trace fossils. Typically, trace fossils are named and compared morphologically with others in the ichnotaxon and may commonly be assigned to behavioral groups (e.g. Pickerill 1992, Buatois \& Mangano 2004, 2007). However, it is less common for a possible tracemaker to be suggested (but see Bromley \& Asgaard 1979, Pickerill 1992, Metz 1996). Beyond trace fossil morphology, studies focus typically on documenting the facies distributions and trace fossil assemblages and on comparing them with those in other lacustrine strata.

Three lacustrine ichnofacies have been recognized. The Mermia ichnofacies (see e.g. Buatois \& Mangano 1995, 2007) is an association of surficial tracks and trails, and shallow endostratal trails, interpreted as feeding and locomotion traces produced in perpetually submerged environments; trace fossils are nonpenetrative and preserved on bedding surfaces. The Mermia ichnofacies occurs in shallow to deep lacustrine facies (Buatois \& Mangano 2007; reduction in ichnotaxonomic diversity with decreasing depth has been documented; Melchor 2004). Co-occurrence of Mermia and Scoyenia ichnofacies trace fossils have been interpreted as overprinting of marginal lacustrine bioturbation on biogenic structures produced in permanently submerged sediments (Kim et al. 2005); this corroborates extension of the Mermia ichnofacies into very shallow water. Because Mermia ichnofacies trace fossils occur in other ichnofacies, modifications in terminology have been suggested to make them more distinctive (Kim et al. 2005).

Broadly, the structures produced by the typical lake benthos described herein resemble the trace fossils of the Mermia ichnofacies. Both the modern structures and components of the Mermia ichnofacies are morphologically simple and most are produced near the sediment-water interface (see Fig. 4A,B,C,G). Missing from the Mermia ichnofacies, however, are the more deeply penetrative traces produced by chironomids, oligochaetes, and ephemerids, along with zones of intensely bioturbated sediment reworked by oligochaetes or amphipods. Trace fossils of the Mermia ichnofacies are interpreted generally to have been produced by insects, crustaceans, worms, and fishes (e.g. Pickerill 1992, Buatois \& Mangano 1995), but there have been few detailed studies linking the behavior of modern lacustrine animals to the trace fossils.

The Skolithos ichnofacies is an association of lowdiversity vertical burrows, and has been identified in sandstones deposited in high-energy, lake-margin environments (Buatois \& Mangano 2007). However, it has not been widely reported from ancient lacustrine sequences, and no tracemakers have been identified. Insect diversity and abundance are much lower in sands than in other substrate types, and no organism is known that produces deep vertical burrows in mobile, shallow-water, lacustrine sands. Burrowing immature mayflies produce U-shaped burrows, but they are most common in quiet water settings.

The third association, the Scoyenia ichnofacies, is indicative of low-energy, lake-margin habitats that experience both subaqueous and subareal conditions (Kim et al. 2005, Buatois \& Mangano 2007). The Scoyenia ichnofacies includes arthropod tracks and trails, plant traces, and vertebrate tracks (e.g. Frey \& Pemberton 1987, Buatois \& Mangano 2007). Many of the producers were probably terrestrial or semi-terrestrial rather than fully aquatic: greater diversity of semiterrestrial burrowers than aquatic infaunal animals is well documented (e.g. Hasiotis 2007). Scoyenia itself and other traces that result in pervasive disruption of the sediment (e.g. Fuersichnus; Bromley \& Asgaard 1979) have not been linked to modern lake-margin burrowers.

Most lacustrine trace fossils are shallowly penetrative and are thus found on bedding planes rather than on vertical surfaces (e.g. Miller et al. 2002). In contrast, most lake sediments are studied in cores, benthic animals are obtained from grab samples, and there is little opportunity to see traces in plain view. Observation and investigation of modern lake traces and sedimentary structures is hampered by the absence of tidal flats, which give easy access to infaunal animals and 
surrounding sediment. Extensive studies of the tidal flats of the North Sea (and elsewhere) have provided information on the behavior of modern marine animals that has enhanced interpretation of trace fossils (Schafer 1972, Cadée \& Goldring 2007), but similar investigations are not feasible in lacustrine sediments. The water cover and turbid conditions produced by easily re-suspended sediment make even observation of surficial traces difficult. Finally, much of the terminology used in ichnology comes from studies of the marine realm, making it difficult to integrate with limnological terms.

\section{HOW PERVASIVE IS BIOTURBATION IN MODERN AND ANCIENT LAKE DEPOSITS?}

Compared with ecological studies of lake benthos, there have been few bioturbation studies, and bioturbation changes over geological time have not been assessed. Further work needs to be carried out because: (1) the extent and style of biologic sediment reworking affects degradation and remineralization of organic matter and, thus, carbon cycling (e.g. Aller 1994, Mermillod-Blondin et al. 2004); (2) the degree of bioturbation affects the resolution of paleoclimate reconstructions from lake sediments; and (3) the depth and facies distribution of bioturbation and biogenic structures in lacustrine deposits through the Phanerozoic is key to reconstructing colonization history of lacustrine benthic habitats. Of particular interest is documenting how bioturbators responded to the postSilurian increase in detritus from vascular plants and the effect of their activity on global carbon cycling (Park \& Gierlowski-Kordesch 2007).

\section{Modern lacustrine sediments}

Most lacustrine sediment investigations are based on detailed analysis of only a few cores (e.g. Martin et al. 2005). In one of the few recent studies in which lake sediments were densely sampled (Schiefer 2006: 202 cores taken in a grid pattern every $100 \mathrm{~m}$ in a $2 \mathrm{~km}^{2}$ glacial lake with a maximum depth of $44 \mathrm{~m}$ ), varved sediments were found to cover $58 \%$ of the lake bottom; massive (poorly sorted) shallow water sediments, $13 \%$; deltaic deposits, $10 \%$; and transitional sediments, $19 \%$. Of these, the varved, massive, and deltaic sediments were not affected by animal activity; bioturbation and biogenic structures were restricted to sediments transitional between the varved and massive sediments at depths between 3 and $12 \mathrm{~m}$, depths comparable to the benthos concentration zones of Mackie (2001). The distribution of burrowed sediment in this lake was con- sistent with the highest density of benthos in sublittoral zones and its paucity in deeper areas. Data from Schiefer (2006) imply that even shallow lakes would have only small areas where sediment reworking by animals would be significant.

\section{Bioturbation in ancient lacustrine stratigraphic sequences}

Ichnologic studies of ancient lacustrine deposits often do not provide abundance data (e.g. Buatois \& Mangano 1995, Melchor 2004; but see Pickerill 1992), and the abundance of bioturbation is only rarely evaluated (Miller et al. 2002, Melchor 2004). In the absence of such datasets, $>50$ of the descriptions of lacustrine sequences (Permian to Holocene) were reviewed for records of bioturbation (Gierlowski-Kordesch \& Kelts 2000). No study reported extensive and pervasive bioturbation. Similarly, despite its importance as a potential mixing process, bioturbation is typically not mentioned in descriptions of cores from Pleistocene and Holocene lacustrine deposits sampled for high-resolution paleoclimate studies (see e.g. numerous studies published in the Journal of Paleolimnology between 2004 and 2007). Paucity of reported bioturbation in ancient lacustrine deposits may result from the fact that it was not the focus of the studies. The lack of appropriate datasets underscores the need for quantitative or semi-quantitative evaluation of the abundance and distribution of biogenic structures in ancient deposits in order to reconstruct the history of lake benthos through the Phanerozoic.

\section{SUMMARY}

In contrast to marine settings, lake systems are strongly affected by local geochemical and climate conditions. These determine nutrient content and mixing processes, which, in turn, control environmental conditions in the water column and substrate and exert a strong influence on the benthic fauna. The most common bottom-dwelling animals in lakes are bivalves, snails, oligochaete worms, crustaceans, and immature insects including chironomids, ephemerids, and chaoborids. The majority are small, soft-bodied shallow burrowers that feed on deposited organic matter. Their distributions are patchy, and are mostly controlled by food resources and water chemistry, including oxygen availability. Although a variety of benthic animals are capable of bioturbation, sensitivities to environmental conditions probably restrict their distribution and abundance in many lake systems. Maximum abundance and diversity generally occur in relatively nar- 
row sublittoral concentration zones, but there is little information on the distribution of biogenic structures and bioturbation in modern lake sediments.

Lacustrine ichnology has focused on describing trace fossils, primarily those preserved on bedding planes, documenting their facies distributions and identifying ichnofacies. Rarely are trace fossils interpreted in light of the behavior of modern lacustrine trace producers, and rarely are ichnofacies integrated with what is known about the distributions of modern lacustrine benthic animals. In addition, there is very little information available on abundance of biogenic structures and extent of bioturbation in either modern or ancient lake deposits. As such, the shapes and patterns of traces and tracks produced by extant lacustrine benthos described in this study are a potentially useful ichnological tool.

Lacustrine ichnology can contribute significantly to understanding the flux of materials between the substrate and overlying water, interpreting paleoclimate, unraveling the colonization history of lacustrine substrates, and reconstructing lake histories. However, this potential will be realized only when it is linked to the study of trace fossils and when gaps in the knowledge of the abundance and distribution of bioturbation in both modern and ancient lacustrine deposits are closed.

Acknowledgements. We thank James Ramsey and Brooke Traynham for discussions on Chironomus and Hexagenia burrows. We thank Sibyl Graber for her patience and skill in helping to capture burrows and traces in situ. James Ramsey and a number of reviewers added to the clarity of the manuscript. D.S.W. was supported by the Center for Reservoir Research, Murray State University. M.F.M. was supported by NSF OPP 0126146 and OPP 0940954.

\section{LITERATURE CITED}

Aller RC (1994) Bioturbation and remineralization of sedimentary organic matter: effects of redox oscillation. Chem Geol 114:331-345

Brinkhurst RO (1974) The benthos of lakes. St. Martins Press, New York

Brinkhurst RO, Cook DG (eds) (1980) Aquatic oligochaete biology. Plenum Press, New York

Brinkhurst RO, Jamieson BGM (1971) The aquatic Oligochaeta of the world. Oliver \& Boyd, Edinburgh

Bromley RG (1996) Trace fossils: biology and taphonomy. Unwin Hyman, London

Bromley R, Asgaard U (1979) Triassic freshwater ichnocoenoses from Carlsberg Fjord, East Greenland. Palaeogeogr Palaeoclimatol Palaeoecol 28:261-281

Buatois LA, Mangano MG (1995) The paleoenvironmental and paleoecological significance of the lacustrine Mermia ichnofacies: an archetypical subaqueous nonmarine trace fossil assemblage. Ichnos 4:151-161

Buatois LA, Mangano MG (2004) Animal-substrate interactions in freshwater environments: applications of ichnology in facies and sequence stratigraphic analysis of fluvio-lacustrine successions. In: McIlroy D (ed) The application of ichnology to palaeoenvironmental and stratigraphic analysis. Geol Soc Spec Publ 228:311-334

Buatois LA, Mangano MG (2007) Invertebrate ichnology of continental freshwater environments. In: Miller W III (ed) Trace fossils: concepts, problems, prospects. Elsevier, New York, p 285-323

Cadée C, Goldring R (2007) The Wadden Sea, cradle of invertebrate ichnology. In: Miller W III (ed) Trace fossils: concepts, problems, prospects. Elsevier, New York, p 3-13

Carr JF, Hiltunen JK (1965) Changes in the bottom fauna of western Lake Erie from 1930 to 1961. Limnol Oceanogr 10:551-569

Ford B (1962) The vertical distribution of larval Chironomidae (Dipt.) in the mud of a stream. Hydrobiologia 19:262-272

Frey RW, Pemberton SG (1987) The Psilonichnus ichnocoenose, and its relationship to adjacent marine and nonmarine ichnocoenoses along the Georgia coast. Bull Can Petrol Geol 35:333-357

Gierlowski-Kordesch EH, Kelts KR (2000) Lake basin through space and time. AAPG Stud Geol 46, Amer Assoc Petrol Geol, Tulsa

Gingras M, LaLond SV, Amskold L, Konhauser KO (2007) Wintering chironomids mine oxygen. Palaios 22:433-438

Harman WN, Berg CO (1971) The freshwater snails of central New York with illustrated keys to the general and species search. Cornell University, Ithaca, NY

Hasiotis ST (2007) Continental ichnology: fundamental processes and controls on trace fossil distribution. In: Miller W III (ed) Trace fossils: concepts, problems, prospects. Elsevier, New York, p 268-284

Hasiotis ST, Mitchell CE (1993) A comparison of crayfish burrow morphologies: Triassic and Holocene fossil, paleoand neo-ichnological evidence and the identification of their burrowing signatures. Ichnos 2:291-314

Horwitz PJ, Richardson AMM (1986) An ecological classification of the burrows of Australian freshwater crayfish. Aust J Mar Freshw Res 37:237-242

Hutchinson GE (1993) A treatise on limnology, Vol 4. The zoobenthos. Wiley \& Sons, New York

> Keilty TJ, White DS, Landru PF (1988) Short term lethality and sediment avoidance assays with endrin-contaminated sediment and two oligochaetes from Lake Michigan: Stylodrilus heringianus (Lumbriculidae) and Limnodrilus hoffmeisteri (Tubificidae). Arch Environ Contam Toxicol 17:95-101

Kim JY, Keighley DG, Pickerill RK, Hwang W, Kim KS (2005) Trace fossils from marginal lacustrine deposits of the Cretaceous Jinju Formation, southern coast of Korea. Palaeogeogr Palaeoclimatol Palaeoecol 218:105-124

Linevich AA (1971) The Chironomidae of Lake Baikal. Limnologica 8:51-52

Mackie GL (2001) Applied aquatic ecosystem concepts. Kendall/Hunt, Dubuque

Mackie GL, White DS, Zdeba TW (1980) A guide to the freshwater mollusks of the Laurentian Great Lakes with special emphasis on the genus Pisidium. EPA-600/3-89-068, US EPA, Duluth

Madenjian CP, Schloesser DW, Kriege KA (1998) Population models of burrowing mayfly recolonization in western Lake Erie. Ecol Appl 8:1206-1212

Martin P, Goddeeris B, Martens K (1994) Depth distribution of oligochaetes in Lake Baikal (Siberia-Russia). Hydrobiologia 278:151-156

Martin P, Boes X, Goddeeris B, Fagel N (2005) A qualitative assessment of the influence of bioturbation in Lake Baikal sediments. Global Planet Change 46:87-99 
Marzolf GR (1965) Substrate relations of the burrowing amphipod Pontoporeia affinis in Lake Michigan. Ecology 46:579-592

McMahon RF, Bogan AE (2001) Mollusca: Bivalvia. In: Thorp $\mathrm{H}$, Covich AP (eds) Ecology and classification of North American freshwater invertebrates, 2nd edn. Academic Press, New York, p 331-429

Melchor RN (2004) Trace fossil distribution in lacustrine deltas: examples from the Triassic rift lakes of the Ischigualasto-Villa Union Basin, Argentina. In: McIlroy D (ed) The application of ichnology to palaeoenvironmental and stratigraphic analysis. Spec Pub 228, Geological Society, London, p 335-354

Mermillod-Blondin F, Gaudet JP, Gerin M, Desrosiers G, Jose J, Chatelliers MC (2004) Relative influence of bioturbation and predation on organic matter processing in river sediments. Freshw Biol 49:895-912

Merritt RW, Cummins KW, Berg MB (eds) (2007) Aquatic insects of North America, 4th edn. Kendall/Hunt, Dubuque

Metz R (1996) Nonmarine trace fossils from the Late Triassic and Early Jurassic of New Jersey. NJ Acad Sci Bull 41:1-5

Miller MF, White DS (2007) Ecological and evolutionary controls on the composition of marine and lake ichnofacies. In: Miller W III (ed) Trace fossils: concepts, problems, prospects. Elsevier, New York, p 531-544

Miller MF, McDowell TA, Smail SE, Shyr Y, Kem NR (2002) Hardly used habitats: dearth and distribution of bioturbation in Paleozoic and Mesozoic stream and lake deposits. Geology 30:527-530

Miller W III (ed) (2007) Trace fossils: concepts, problems, prospects. Elsevier, New York

Park LE, Gierlowski-Kordesch EH (2007) Paleozoic lake faunas: establishing aquatic life on land. Palaeogeogr Palaeoclimatol Palaeoecol 249:160-179

Pickerill RK (1992) Carboniferous nonmarine invertebrate ichnocoenoses from southern New Brunswick, eastern Canada. Ichnos 2:21-35

Pinder LCV (1995) The habitats of chironomid larvae. In:

Submitted: January 4, 2008; Accepted: March 18, 2008
Armitage PD, Cranston PS, Pinder LCV (eds) The Chironomidae. Chapman \& Hall, London, p 107-135

Rhoads DC (1974) Organism sediment relations on the muddy sea floor. Oceanogr Mar Biol Annu Rev 12:263-300

Robbins JA, Keilty TJ, White DS, Edgington DN (1989) Relationships between tubificid abundances, sediment composition, and accumulation rates in Lake Erie. Can J Fish Aquat Sci 46:223-231

Schafer W (1972) Ecology and palaeoecology of marine environments. Oliver \& Boyd, Edinburgh

Schiefer E (2006) Contemporary sedimentation rates and depositional structures in a montane lake basin, southern Coast Mountains, British Columbia. Earth Surf Process Landf 31:1311-1324

Stevenson RJ, Stoermer EF (1981) Quantitative differences between benthic algal communities along a depth gradient in Lake Michigan. J Phycol 17:29-36

Thorp JH, Covich AP (eds) (2001) Ecology and classification of North American freshwater invertebrates. Academic Press, New York

Wetzel RG (2001) Limnology, lake and river ecosystems. Academic Press, New York

White DS, Roughley R (2007) Aquatic Coleoptera. In: Merritt R, Cummins K, Berg M (eds) Aquatic insects of North America, 4th edn. Kendall/Hunt, Dubuque, p 399-473

White DS, Winnell M, Zawacki C, LaDronka R, Zdeba T, Mozley S (1986) Ecology of the macrozoobenthos in the vicinity of the Donald C. Cook nuclear plant. In: Rossmann R (ed) Southeastern nearshore Lake Michigan: impact of the Donald C. Cook nuclear plant. Publication 22, Great Lakes Research Division, University of Michigan, Ann Arbor, p 253-283

Wu WI (1987) The burrowing of Anodonta cygnea (Linnaeus, 1758) (Bivalvia: Unionidae). Bull Malacol Rep China 13: $29-41$

Zdeba TW, White DS (1985) Pisidiidae. Spec Rept 13, Great Lakes Research Division, University of Michigan, Ann Arbor

Proofs received from author(s): May 19, 2008 